\title{
Morphological characterization of indigenous and crossbred pigs in rural and peri-urban areas of southwestern Nigeria
}

\author{
Adeniyi Charles Adeola*, Saidu O. Oseni, Ofelia Galma Omitogun \\ Department of Animal Sciences, Obafemi Awolowo University, Ile-Ife, Nigeria; ${ }^{*}$ Corresponding Author: chadeola@yahoo.com
}

Received 14 May 2013; revised 20 June 2013; accepted 28 June 2013

Copyright (C) 2013 Adeniyi Charles Adeola et al. This is an open access article distributed under the Creative Commons Attribution License, which permits unrestricted use, distribution, and reproduction in any medium, provided the original work is properly cited.

\begin{abstract}
We sought to determine morphological descriptors of Nigerian indigenous pigs (NIP) and crossbred pigs (CBP) based on relationships among live weight (LW) and a suite of 18 morphometric measurements plus the number of teats. We sampled four locations in southwestern Nigeria and obtained data for a total of 120 NIP and CBP. More female pigs $(61.7 \%)$ than males $(38.3 \%)$ were sampled, and they had a mean live weight of $19.9 \pm 6.10 \mathrm{~kg}$ (range $9-32 \mathrm{~kg}$ ) and $20.1 \pm 6.08$ kg (range 8 - $37 \mathrm{~kg}$ ), respec- tively. The NIP had a longer snout, wider head and longer erect ears than CBP ( $P<0.0001)$. Morphological variables that were highly correlated with LW included neck circumference (NC), breast height (BH), rump height $(R H)$, body length $(B L)$, interorbital width (IW), paunch girth (PG), hearth girth (HG), tail length (TL) and length of snout (LS) with Spearman correlation coefficients $\left(R^{2}\right)$ of 0.97 , $0.92,0.96,0.97,0.91,0.97,0.97,0.90$, and 0.93 , respectively (all $P<0.0001$ ). Teat number for NIP ranged from 5 to 14 while the CBP had a range of 10 to 16 teats. For male NIP, HG and TL best-fit in the model for body weight prediction (LW = $-25.71+0.43$ HG + 2.21 TL; $R^{2}=0.93 ; P<0.0001$ ), while HG and IW had the best-fit for the female NIP $\left(L W=-28.27+0.50\right.$ HG + 2.22 IW; $R^{2}=0.96$ $P<0.0001)$. Models for male and female CBP were $L W=-8.89+0.32 R H+0.34 B L\left(R^{2}=0.84 ; P\right.$ $<0.0001)$ and $L W=-13.01+0.44 R H+0.27 B L\left(R^{2}\right.$ $=0.94 ; P<0.0001)$, respectively. Thus, for these populations of pigs, LS and TN differentiated NIP from CBP, because the NIP consistently recorded longer LS and les- ser TN.
\end{abstract}

Keywords: Nigerian Indigenous Pigs; Live Weight;
Morphological Descriptors; Relationship

\section{INTRODUCTION}

Pigs are one of the most prolific and fast growing livestock that can convert food waste to valuable products. The value of a pig carcass for meat production depends primarily on carcass weight and on the relative proportions of fat and lean meat. As consumer preferences become more specific, the shape of retail cuts and, thus, carcass conformation plays an increasingly significant role in the pork industry [1]. Pigs have several advantages over other species of farm animals including high prolificacy involving the possibility of two or more litters per year. Hence, experimental lines can be produced faster than most other farm animals [2]. In many societies in the developing world, indigenous pigs are the favourite monogastric mammal rural families used to supplement protein intake and family income because of their less intensive management and feed requirements [3]. Pig production is relatively inexpensive due to fast growth rate, short generation interval and high production potential, prolific fecundity [4,5], highly efficient carcass yield and high adaptability to varied environmental conditions. The intake of protein in Nigeria stands at $3.5 \mathrm{~g} /$ caput/day [6] and this is far less than the $35 \mathrm{~g}$ caput/day recommended by the World Health Organization. Limited information exists on the relationship between body weight and linear measurements for Nigerian indigenous pigs (NIP) and their crossbreed pigs (CBP) with exotic forms such as Large White. Such inferences are important in anthropogenic selection for frame size, drug administration, feeding, and marketing of live weight and carcasses, among other potential applications. For example, morphometric measurements characterize and establish breed standards in the production of West African Dwarf (WAD) goats in rural com- 
munities [7]. Linear body measurements are closely related to live weights for pigs [8-10] and in other farm animals including goats and sheep [11], poultry [12], cattle [13], and rabbits [14]. Such zoometrical measurements of body parts can predict live weight at relatively lower costs with a high relative accuracy and consistency.

The objectives of this study are to determine relationships among body weight and linear measurements in NIP and their CBP particularly crosses between NIP and Large White, and to establish morphological descriptors for this composite pig population.

\section{MATERIALS AND METHODS}

\subsection{Study Sites}

The study was conducted in southwestern Nigeria. The region was located between $7^{\circ}$ and $9^{\circ} \mathrm{S}$ and between $3^{\circ}$ and about $6^{\circ} \mathrm{W}$. The study sites were located at elevations ranging from 200 to 500 meters above sea level. The region enjoyed abundant and reliable rainfall from April through October.

One hundred twenty samples of pigs were collected from four different locations of more than $100 \mathrm{~km}$ apart. Forty one CBP were from Obafemi Awolowo University (OAU), Teaching and Research Farm (T \& R Farm), Osun State; these pigs had a history of over 5 years crossbreeding between selected or introduced commercial exotic founder stocks that were contaminated with other breeds of pigs. The remaining three locations contained indigenous pigs. First, 30 NIP were from Ogbooro, Saki Oyo State. Local pigs kept in a mud house were released to roam about the village. This area was dominated by Muslims who do not rear or eat pigs; a few educated Christian families inherited the animals from their forefathers and this, to some extent, restricted infiltration by other breeds of pigs from the neighbouring States. Second, 16 NIP were from the Institute of Agricultural Research and Training (IAR\&T), Ibadan, Oyo State. They were kept on a research farm and had regular feeding and record-keeping for each animal. Third, 33 pigs were from Igbara Odo, Ekiti State. These local pigs were allowed to roam about scavenging for survival and they had a history of being reared for over many years. These areas were identified and confirmed to have uncontaminated NIP after our field reconn aissance survey of the states around OAU and personal interviews of the pig farmers.

\subsection{Linear Body Measurements}

The following 18 linear body measurements and count were taken: 1) head width (HeW), the distance between the two zygomatic arches; 2) head length (HL), the distance between the snout and occipital tip of the animal; 3) rump width (RW), the distance between the external iliac tuberosities; 4) rump length (RL): the distance between the end of ischion and the beginning of the rump (external iliac tuberosity); 5) rump height (RH), the distance between the highest point of the hip bone and the ground; 6) length of snout (LS), the distance between the frontal nasal suture and upper part of the snout; 7) breast height $(\mathrm{BH})$, the distance between the withers most sloping part and the sternum most curved part; 8) wither height (WH), the distance between the highest part of wither and the ground; 9) body length (BL), the distance from the point of the shoulder to the pin bone; 10) interorbital width (IW), the shortest distance between the two eye sockets; 11) paunch girth (PG), the length of the circumference of the pelvic region just in front of the hip; 12) heart girth (HG), the length of the circumference immediately behind the front legs; 13) neck circumference (NC), the length of the circumference of the neck; 14) ear length (EL), the distance between the tip of the ear and the base; 15) hip width (HW), the distance between the points of the hip (hindquarters); 16) shoulder width (SW), the distance between the points of the shoulder; 17) tail length (TL), the distance from the tip to the base of the tail; 18) live weight (LW), the live animal body weight; and 19) the teat number (TN), that observed for the each animal sampled.

Each animal was gently restrained while taking the measurements. The body weights in kilogram were recorded with the aid of weighing scale while the linear body measurements in centimetre were recorded using a tape. Animal ages were estimated by stage of dental growth as described by [15] and pigs were assigned to one of three in age-groups: $4-12,12-24$, and $24-48$ months.

Means and standard error for body weight and linear body measurements were calculated using the General Linear Model Procedure of SAS software. The simple Linear Correlation Procedure of SAS was used to establish the strength of linear relationship and association between the different linear body measurements together with the bodyweight. Linear and multiple regression analysis were carried out using the PROC REG procedures of [16], and the stepwise model selection option. Prediction equations that related to body weight and linear body measurements were chosen based on values of the adjusted $\mathrm{R}^{2}$ and $\mathrm{RSD}$, reporting the equation with the highest $\mathrm{R}^{2}$ and the lowest RSD values.

We employed the following model:

Yij $=a+b i x i+$ eij

Where:

Yij = the dependent variable body weight, $\mathrm{a}=$ Intercept, $\mathrm{bi}=$ partial regression coefficient of the dependent variable, $x i=i$ th independent variable, eij $=$ random error. 


\section{RESULTS AND DISCUSSION}

This study sampled more female pigs $(61.7 \%)$ than males $(38.3 \%)$ with a mean live weight of $19.9 \pm 6.10 \mathrm{~kg}$ (range $9-32 \mathrm{~kg}$ ) and $20.1 \pm 6.08 \mathrm{~kg}(8-37 \mathrm{~kg})$, respectively. This structure reflected the population of pigs generally kept by subsistence peasant farmers in rural areas. Generally, rural farmers were artistic breeders who naturally and traditionally knew that a constant flock size essentially depends on a large number of reproductively active females that must be kept for long periods of time.

The means of live body weight and other morphological measurements for all animals sampled were summarized in Table 1. The CBP sampled from Research Farm, $\mathrm{OAU}$, had a mean live weight of $17.1 \mathrm{~kg}$ in the 4 24-month age group. NIP sampled from Igbara Odo had a mean live weight of $22.4 \mathrm{~kg}$. Within the population sampled at IAR\&T, the mean body weight was $18.1 \mathrm{~kg}$. The mean live weight for samples from Ogbooro was $22.1 \mathrm{~kg}$. The location of sampling did not have any effect on WH, RL, and RW $(\mathrm{P}<0.05)$. The weight of the NIP ranged between 11 and $37 \mathrm{~kg}$ with the overall mean weight of $21.4 \pm 6.40 \mathrm{~kg}$; these animals were in 12 48-month age group.

Correlation coefficients among live weight and morphometric traits in NIP and CBP were shown in Table 2. Morphological variables that were highly correlated with body weight included NC, BH, RH, BL, IW, PG, HG, TL, and LS with correlation coefficients of 0.97, 0.92, 0.96, $0.97,0.91,0.97,0.97,0.90$, and 0.93 , respectively (in all $\mathrm{P}<0.0001)$. This indicated that, depending on genetic correlations, selection for these traits could have resulted in responses in the correlated traits.

The NIP had longer snout, wider head, and longer erect ears than the CBP $(\mathrm{P}<0.0001)$ (Table 3). The TN recorded for the NIP had a mean of $11.5 \pm 1.76$ with a range of 5 - 14 indicating an odd number along the belly line. In comparison, the CBP had a range of from 10 to 16 teats, with a mean of $14.0 \pm 1.46$. The best prediction equation for NIP was $\left(\mathrm{LW}=-5.03+0.58 \mathrm{HG} ; \mathrm{R}^{2}=0.89\right)$ while that of $\mathrm{CBP}$ was $\left(\mathrm{LW}=-5.95+0.51 \mathrm{BL} ; \mathrm{R}^{2}=\right.$ 0.83 ) (Table 4). The multiple regression model for male

Table 1. Least-squares means for the morphological variable analyzed for each location.

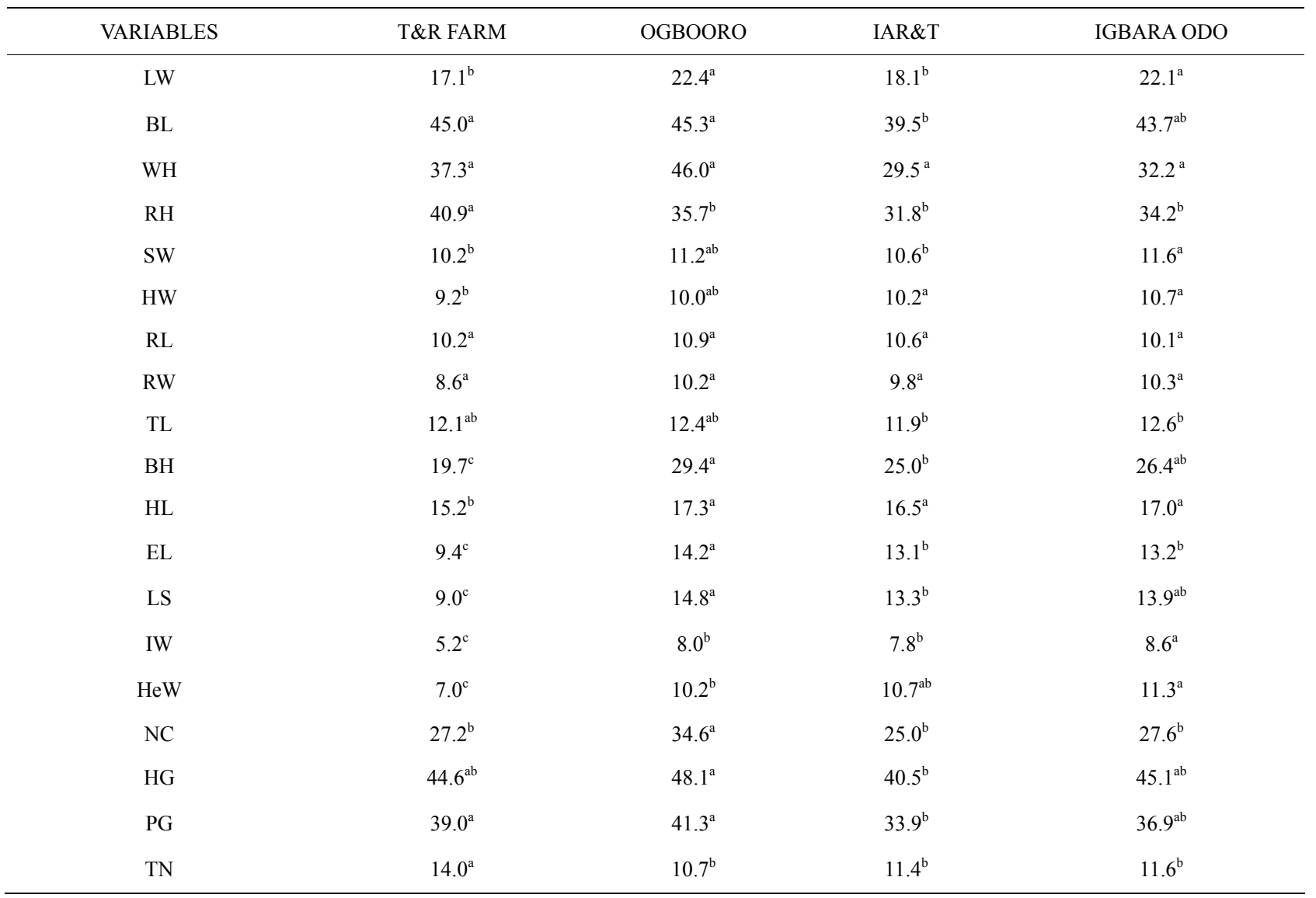

\footnotetext{
${ }^{* * *}$ Means within a row with the same superscripts are not significantly different $(\mathrm{P}<0.05)$. T\&R Farm: Crossbred samples from Teaching and Research farm; Igbara, IAR\&T, Ogbooro are the local animals sampled from Igbara Odo, IAR\&T and Ogbooro respectively. TN $=$ measured by counting, LW $=$ measured in kg and other variables measured in $\mathrm{cm} ; \mathrm{LW}=$ live weight, $\mathrm{BL}=$ body length, $\mathrm{WH}=$ wither height, $\mathrm{RH}=$ rump height, $\mathrm{SW}=$ shoulder width, $\mathrm{HW}=$ hip width, $\mathrm{RL}=$ rump length, $\mathrm{RW}=$ rump width, $\mathrm{TL}=$ tail length, $\mathrm{BH}=$ breast height, $\mathrm{HL}=$ head length, $\mathrm{EL}=$ ear length, $\mathrm{LS}=$ length of snout, $\mathrm{IW}=$ inter orbital width, $\mathrm{HeW}=$ head width, $\mathrm{NC}=$ neck circumference, $\mathrm{HG}$ = heart girth, $\mathrm{PG}=$ paunch girth.
} 
Table 2. Correlation coefficients among live weight and morphometric traits in NIPs and crossbred pigs.

\begin{tabular}{|c|c|c|c|c|c|c|c|c|c|c|c|c|c|c|c|c|c|c|c|}
\hline Location & Sex & Age & $\mathrm{BL}$ & $\mathrm{WH}$ & $\mathrm{RH}$ & SW & HW & $\mathrm{RL}$ & RW & $\mathrm{TL}$ & $\mathrm{BH}$ & $\mathrm{HL}$ & EL & LS & IW & $\mathrm{HeW}$ & $\mathrm{NC}$ & HG & PG \\
\hline All & M & All & 0.83 & 0.70 & 0.61 & 0.62 & & & 0.61 & 0.66 & 0.83 & & 0.66 & 0.66 & 0.60 & & 0.79 & 0.79 & 0.74 \\
\hline All & $\mathrm{F}$ & All & 0.86 & & 0.70 & & & & 0.62 & & 0.85 & & & & & & 0.76 & 0.83 & 0.74 \\
\hline $\mathrm{T} \& \mathrm{R}$ & Both & All & 0.91 & 0.88 & 0.86 & & & & & & & & & & & & & & \\
\hline$T \& R$ & Both & $4-12$ & 0.86 & 0.94 & 0.88 & & & & & & & & & & & & & & \\
\hline$T \& R$ & Both & $12-24$ & 0.82 & 0.71 & & & & & & & & & & & & & & & \\
\hline Igbara & Both & All & 0.94 & & 0.92 & 0.64 & 0.70 & 0.66 & 0.74 & 0.68 & 0.92 & 0.81 & 0.92 & 0.93 & 0.73 & 0.70 & 0.93 & 0.95 & 0.93 \\
\hline IAR\&T & Both & All & 0.97 & 0.90 & 0.95 & 0.89 & 0.87 & 0.90 & 0.93 & 0.90 & 0.90 & & 0.67 & 0.85 & 0.91 & & 0.97 & 0.97 & 0.96 \\
\hline Ogbooro & Both & All & 0.95 & 0.96 & 0.96 & 0.88 & 0.62 & 0.74 & 0.63 & 0.67 & 0.93 & 0.55 & 0.72 & 0.79 & 0.79 & 0.67 & 0.93 & 0.96 & 0.97 \\
\hline Local & Both & All & 0.93 & & 0.91 & 0.71 & 0.61 & 0.68 & 0.71 & 0.72 & 0.90 & 0.69 & 0.76 & 0.82 & 0.72 & & 0.83 & 0.94 & 0.89 \\
\hline Local & Both & $12-24$ & 0.88 & 0.78 & 0.79 & & & & & 0.76 & 0.65 & & 0.74 & 0.83 & 0.77 & & 0.70 & 0.90 & 0.80 \\
\hline Local & Both & $24-48$ & 0.91 & & 0.88 & & & & & & 0.87 & & & & & & 0.71 & 0.92 & 0.83 \\
\hline
\end{tabular}

$\mathrm{P}<0.0001$ level of significance. N.B: Only $\mathrm{P}<0.0001$ level of significance were included in the table. All: this is the all the 120 animals sampled from the four different locations; Local: this is the 79 local animals sampled from the three different locations; T\&R: Crossbred samples from Teaching and Research farm; Igbara, IAR\&T, Ogbooro are the local animals sampled from Igbara Odo, IAR\&T and Ogbooro respectively. $\mathrm{LW}=$ live weight, $\mathrm{BL}=$ body length, WH $=$ wither height, $\mathrm{RH}=$ rump height, $\mathrm{SW}=$ shoulder width, $\mathrm{HW}=$ hip width, $\mathrm{RL}=$ rump length, $\mathrm{RW}=$ rump width, $\mathrm{TL}=$ tail length, $\mathrm{BH}=$ breast height, $\mathrm{HL}=$ head length, $\mathrm{EL}=$ ear length, $\mathrm{LS}=$ length of snout, $\mathrm{IW}=$ inter orbital width, $\mathrm{HeW}=$ head width, $\mathrm{NC}=$ neck circumference, $\mathrm{HG}=$ heart girth, $\mathrm{PG}=$ paunch girth .

Table 3. Least-squares means by breed type and the corresponding levels of significance.

\begin{tabular}{ccc}
\hline Variables $(\mathrm{cm})$ & Crossbred pigs & Local pigs \\
\hline LW & $20.5^{\mathrm{a}}$ & $16.4^{\mathrm{b}}$ \\
BL & $50.3^{\mathrm{a}}$ & $36.6^{\mathrm{b}}$ \\
WH & $40.7^{\mathrm{a}}$ & $26.1^{\mathrm{b}}$ \\
RH & $44.1^{\mathrm{a}}$ & $28.0^{\mathrm{b}}$ \\
SW & 10.8 & 10.4 \\
HW & $9.9^{\mathrm{a}}$ & $9.7^{\mathrm{b}}$ \\
RL & 11.1 & 10.3 \\
RW & $9.4^{\mathrm{a}}$ & $9.5^{\mathrm{b}}$ \\
TL & $12.5^{\mathrm{a}}$ & $12.0^{\mathrm{b}}$ \\
BH & 21.1 & 22.0 \\
HL & 15.5 & 16.3 \\
EL & $10.3^{\mathrm{a}}$ & $12.95^{\mathrm{b}}$ \\
LS & $9.9^{\mathrm{a}}$ & $13.5^{\mathrm{b}}$ \\
IW & $5.6^{\mathrm{a}}$ & $7.9^{\mathrm{b}}$ \\
HeW & $7.9^{\mathrm{a}}$ & $10.3^{\mathrm{b}}$ \\
NC & $28.8^{\mathrm{a}}$ & $24.3^{\mathrm{b}}$ \\
HG & $45.6^{\mathrm{a}}$ & $38.0^{\mathrm{b}}$ \\
PG & $40.7^{\mathrm{a}}$ & $31.0^{\mathrm{b}}$ \\
TN (No.) & $14.0^{\mathrm{a}}$ & $11.5^{\mathrm{b}}$ \\
\hline
\end{tabular}

Crossbred pigs (Crossbred); Local pigs: Nigerian Indigenous Pigs (NIPs) Means with the same superscript are not significantly different $(\mathrm{P}<0.05)$. $\mathrm{TN}=$ measured by counting, $\mathrm{LW}=$ measured in $\mathrm{kg}$ and other variables measured in $\mathrm{cm} ; \mathrm{LW}=$ live weight, $\mathrm{BL}=$ body length, $\mathrm{WH}=$ wither height, $\mathrm{RH}=$ rump height, $\mathrm{SW}=$ shoulder width, $\mathrm{HW}=$ hip width, $\mathrm{RL}=$ rump length, $\mathrm{RW}=$ rump width, $\mathrm{TL}=$ tail length, $\mathrm{BH}=$ breast height, $\mathrm{HL}=$ head length, $\mathrm{EL}=$ ear length, $\mathrm{LS}=$ length of snout, $\mathrm{IW}=$ inter orbital width, $\mathrm{HeW}=$ head width, $\mathrm{NC}=$ neck circumference, $\mathrm{HG}=$ heart girth, $\mathrm{PG}=$ paunch girth.
$\mathrm{NIP}$ was $\left(\mathrm{LW}=-25.71+0.43 \mathrm{HG}+2.21 \mathrm{TL} ; \mathrm{R}^{2}=0.93\right)$ and for females $\left(\mathrm{LW}=28.27+0.5 \mathrm{HG}+2.22 \mathrm{IW} ; \mathrm{R}^{2}=\right.$ 0.96). The best model for male $\mathrm{CBP}$ was ( $\mathrm{LW}=-8.89+$ $\left.0.25 \mathrm{RH}+0.35 \mathrm{BL} ; \mathrm{R}^{2}=0.84\right)$ and for females $(\mathrm{LW}=$ $\left.13.01+0.44 \mathrm{RH}+0.27 \mathrm{BL} ; \mathrm{R}^{2}=0.94\right)$. Higher $\mathrm{HG}$ and TL were established as morphometric traits useful for predicting the live weight of male NIP while HG and IW for female NIP in Nigeria. For CBP, BL and RH were useful for predicting live weight in both sexes.

The low mean live weight and body measurements recorded in samples from Igbara Odo, IAR\&T, and Ogbooro show that the NIP are generally smaller than imported commercial pigs and their crossbreds. For example, in Tanzania, [17] recorded a range of live BW, from 30 to $64 \mathrm{~kg}$, in adult local pigs. Similarly [18] reported BWs of $38.9 \pm 1.49 \mathrm{~kg}$ for five months and $106.3 \pm 0.31$ $\mathrm{kg}$ for one year old Ghoongroo pigs in India. These contrasting differences may be driven by environmental influences such as climate, nutrition, and management. However, our study agrees with the findings of [4] that indigenous breeds are smaller with shorter legs than exotic types. Smaller size may yield a greater ability to survive under the harsh conditions than larger size, as an evolutionary adaptation to conditions of low-input production [19]. The longer snout, wider head and longer erect ears indicates that the NIP represents a largely unselected genetic group of pigs [20]. Confirmed higher fat deposition at the shoulder region than at the rump area. Breeds do not differ significantly $(\mathrm{P}<0.05)$ between SW, $\mathrm{HW}, \mathrm{RW}, \mathrm{BH}$, and HL. The longer snout observed in IAR\&T, Igbara Odo, and Ogbooro is characteristic of West African indigenous pigs and this is a distinguishing 
Table 4. Prediction equations for live weight based on stepwise regression analysis in NIPs and Crossbreds.

\begin{tabular}{|c|c|c|c|c|c|c|}
\hline Genotype & Location & Sex & $\begin{array}{c}\text { Simple Regression } \\
\text { Equation }\end{array}$ & Coefficient of Determination & Multiple Regression Equation & $\begin{array}{l}\text { Coefficient of } \\
\text { Determination }\end{array}$ \\
\hline \multirow[t]{3}{*}{ Crossbred } & T\&R Farm & MF & $-5.95+0.51 \mathrm{BL}$ & 0.83 & $-11.47+0.32 \mathrm{RH}+0.34 \mathrm{BL}$ & 0.90 \\
\hline & & M & & & $-8.89+0.25 \mathrm{RH}+0.35 \mathrm{BL}$ & 0.84 \\
\hline & & $\mathrm{F}$ & & & $13.01+0.44 \mathrm{RH}+0.27 \mathrm{BL}$ & 0.94 \\
\hline \multirow[t]{6}{*}{ Local } & Igbara & MF & $-2.08+0.50 \mathrm{HG}$ & 0.91 & & \\
\hline & IAR\&T & MF & $-14.39+0.80 \mathrm{HG}$ & 0.95 & & \\
\hline & Ogbooro & MF & $-11.66+0.91 \mathrm{PG}$ & 0.95 & & \\
\hline & local & MF & $-5.03+0.58 \mathrm{HG}$ & 0.89 & & \\
\hline & local & M & & & $-25.71+0.43 \mathrm{HG}+2.21 \mathrm{TL}$ & 0.93 \\
\hline & & $\mathrm{F}$ & & & $28.27+0.50 \mathrm{HG}+2.22 \mathrm{IW}$ & 0.96 \\
\hline
\end{tabular}

$\mathrm{M}=$ male; $\mathrm{F}=$ female; $\mathrm{MF}=$ male and female Local: 79 locals sampled from three different locations T\&R Farm: Crossbred sampled from Teaching and Research farm Igbara, IAR\&T, Ogbooro are the local animals sampled from Igbara Odo, IAR\&T and Ogbooro respectively TN $=$ measured by counting, LW = measured in $\mathrm{kg}$ and other variables measured in $\mathrm{cm} ; \mathrm{LW}=$ live weight, $\mathrm{BL}=$ body length, $\mathrm{WH}=$ wither height, $\mathrm{RH}=$ rump height, $\mathrm{SW}=$ shoulder width, $\mathrm{HW}=$ hip width, $\mathrm{RL}=$ rump length, $\mathrm{RW}=$ rump width, $\mathrm{TL}=$ tail length, $\mathrm{BH}=$ breast height, $\mathrm{HL}=$ head length, $\mathrm{EL}=$ ear length, $\mathrm{LS}=$ length of snout, IW = inter orbital width, $\mathrm{HeW}=$ head width, $\mathrm{NC}=$ neck circumference, $\mathrm{HG}=$ heart girth, $\mathrm{PG}=$ paunch girth.

physical feature of this genetic group. Previously, [17, 21-23] reported a long, straight, pointed snout, and strong jaws in NIP and local pigs respectively. The odd TN of NIP is similar to Mexican hairless pigs [24], Kele indigenous pigs found in southwest China [25], Chato Murciano pigs [26], local pigs in Tanzania [17] and Majorcan black pigs in Spain [27]. In some cases, the lower TN in the NIP serves to differentiate them from CBP, although the ranges overlap.

\section{CONCLUSION AND RECOMMENDATION}

NIP has the potential to be developed in order to contribute significantly to the indigenous pig industry based on their positive qualities such as a valuable source of meat and secondary income to the rural household economy, the hardiness and adaptability to harsh management conditions and in view of the breed going into extinction. HG fits best in the linear regression model $\left(\mathrm{R}^{2}\right.$ $=0.89$ ), and is useful for predicting body weight in NIP. The character is useful for predicting boar BW [8] and growing-finishing pigs in Kansas State University [28]. When there are no weighing scales, morphometric measurements such as HG, TL, IW, BL, and RH are useful for estimating and predicting the live weight in the NIP and CBP. Similarly, in the absence of a standard ruler in rural areas, we recommend using calibrated sticks.

\section{REFERENCES}

[1] Brown, C. (2004) The changing market: Perspective from multiple retailers. In: Thompson, J.E., Gill, B.P. and Varley, M.A., Eds., The Appliance of Pig Science, British Society of Animal Science, 19-22.

[2] Archibald, A.L. and Haley C.S. (1992) Porcine genome analysis. Strategies for Physical Mapping, 4, 99-129.

[3] Omitogun, O.G. (2004) Analysis of swine genome organization. Evaluation of G-T-G bands in porcine chromosomes for physical mapping. In: Ariyo, O.J., Ikeobi, C.O.N., Omoniyi, T. and Kehinde, O.B., Eds., Proceedings of the 29th Annual Conference of Genetics Society of Nigeria, 54-57.

[4] Holness, D.H. (1991) The tropical agriculturist (Pigs). CTA, Wageningen, 1-29.

[5] Osaro, O.M. (1995) Enhancing production performance of small holder pig farmers. In: Pig Production Workshop Training Manual, NAERLS, A.B.U., Zaria, 100-130.

[6] Ironkwe, M.O. and Amefule, K.U. (2008) Appraisal of indigenous pig production and management practices in Rivers State, Nigeria. Journal of Agriculture and Social Research (JASR), 8, 11-16.

[7] Oseni, S.O., Sonaiya, E.B., Omitogun, O.G., Ajayi, B.A., and Muritala, I. (2006) West African Dwarf Goat Production under village condition: 1. Characterisation and establishment of Breed Standards. Proceedings of Conference on International Agricultural Research for Development, University of Bonn, Tropentag, 1-5.

[8] Sulabo, R.C., Quackenbush, J., Goodband, R.D., Tokach, M.D., Dritz, S.S., DeRouchey, J.M. and Nelssen, J.L. (2006) Validation of flank-to-flank measurement for predicting boar weight. http://www.oznet.ksu.edu/library

[9] Machebe, N. S. and Ezekwe, A.G. (2008) Predicting body weight of growing-finishing gilts reared in the tropics using linear body measurements. Procedure 13th Annual Conference of Animal Science Association of Nigeria (ASAN).

[10] Adedeji, T.A. (2012) Qualitative and quantitative characterization of body morphometric of indigenous pigs in the humid environment of Nigeria. Continental Journal of Animal and Veterinary Research, 4, 11-16.

[11] Ladan, S.A., Egahi, J.O. and Dim, N.I. (2009) Body biometry as a predictive index for body weights in Yankasa ewes under traditional husbandry system in North Central 
Nigeria. Procedure Nigerian Society for Animal Production 34th Annual Conference, 15-18 March 2009.

[12] Akanno, E.C., Ole, P.K., Okoli, I.C. and Ogundu, U.E. (2002) Performance characteristics and prediction of body weight of broiler strains using linear body measurements. Proceedings Nigerian Society for Animal Production 32nd Annual Conference, 18-21 March 2007.

[13] Orheruata, A.M. and Olutogun, O. (1994) Pre and Post weaning phenotypic relationship between some N'dama cattle linear measurement in the tropics. Nigerian Journal of Animal Production, 21, 76-82.

[14] Okoro, V.M.O., Ezeokeke, U.E., Ogundu, U.E. and Chukwudim, C. (2008) Phenotypic correlation between weight and linear body measurement in Chinchilla rabbits. Proceedings 13th Annual Conference of Animal science Association of Nigeria (ASAN), 15-19 September 2008.

[15] Matschke, G.H. (1967) Aging European wild hogs by dentition. Journal of Wildlife Society Bulletin, 21, 269-274.

[16] SAS (2004) SAS users guide: Statistics. Statistical Analysis System Institute. Inc., Cary.

[17] Mbaga, S.H., Lymo, C.M., Kifaro, G.C. and Lekule, F.P. (2005) Phenotypic characterization and production performance of local pigs under village settings in the Southern Highland zone, Tanzania. Animal Genetic Resources Information, 37, 83-90.

[18] Pan, S., Misra, S.K. and Kundu, M.S. (2005) Ghoongroo pig: A new found animal genetic resource of sub-Himalayan West Bengal, India. Animal Genetic Resources Information, 37, 91-96. doi:10.1017/S1014233900002005

[19] Lekule, F.P and Kyvsgaard, N.C. (2003) Improving pig husbandry in tropical resource-poor communities and its potential to reduce risk of porcine Cystercosis. Acta Tropica, 87, 111-117. doi:10.1016/S0001-706X(03)00026-3
[20] Sonaiya, E.B. (1986) Observations on the growth, body dimensions and carcass traits of Nigerian indigenous pigs. Nigerian Journal of Animal Production, 13, 124-130.

[21] Pathiraja, N. and Oyedipe, E.O. (1990) Indigenous pig of Nigeria. Animal Genetic Resources Information, 7, 63-70. doi: $10.1017 / \mathrm{S} 1014233900003023$

[22] Adebambo, O.A. (1994) A proposed Animal Breeding Programme in Nigeria. African animal genetic resources: Their characterization, conservation and utilization. Proceedings of the Resource Planning Workshop ILCA, Addis Ababa, 640.

[23] Ademola, S.G., Ojedapo, L.O., Olayeni, T.B. and Emiola, I.A. (2009) A practical approach to animal production and health. Oluseyi Press Ltd., Ibadan, 36.

[24] Lemus, F.C., Alonso, M.R., Alonso-Spilsbury, M. and Ramirez, N.R. (2003) Morphologic characteristics in Mexican Native Pigs. Arch. Zootec, 52, 105-108.

[25] Cheng, P. (1984) Livestock breeds of China. Animal production and Health, 46.

[26] Peinado, B., Vega-Pla, J.L., Martinez, M.A., Galian, M., Barba, C., Delgado, J.V. and Poto, A. (2006) Chato Muciano pig breed: Genetic and ethno zoological characterization. Animal Genetic Resources Information, 38, $77-$ 86. doi:10.1017/S1014233900002078

[27] Jaume, J. and Alfonso, L. (2000) The Majorcan black pig. Animal Genetic Resources Information, 27, 53-58. doi:10.1017/S1014233900001292

[28] Groesbeck, C.N., Goodband, R.D., DeRouchey, J.M., Tokach, M.D., Dritz, S.S., Nelssen, J.L., Lawrence, K.R. and Young, M.G. (2002) Using heart girth to determine weight in finishing pigs.

http://www.ksre.ksu.edu/library 